\title{
Precarious Bodies: \\ Occupational Risk Assemblages in Bolivia and Trinidad
}

\author{
Rebecca Prentice, University of Sussex, United Kingdom \\ Mei L. Trueba, Brighton and Sussex Medical School, United Kingdom
}

\begin{abstract}
This article develops the concept of "precarious bodies" to theorise the lived experience of labour precariousness in the twenty-first century and its implications for workers' health, well-being and household reproduction. Drawing on ethnographic research with Bolivian miners and Trinidadian garment workers, we explore the relationship between workers' exposure to global market forces and their everyday experiences of work, health and risk in these industries. "Precarious bodies" is a heuristic that takes into a single frame the macro-level economic and regulatory processes that create risks for workers, and the various ways in which workers negotiate these risks through their work practices and livelihood choices. We show precarious bodies to be both vulnerable and strategic. Positioned in situations of exploitation and risk, their choices to protect their livelihoods can harm their health and reinforce - rather than counteract - the precarious circumstances of their households.
\end{abstract}

\section{KEY WORDS}

precarious bodies; occupational risk assemblage; health and safety; Bolivia; Trinidad

\section{Introduction}

New configurations of labour in the global economy have created conditions of worker insecurity, marginalisation and powerlessness that have been broadly theorised in recent years as "precariousness" or "precarity" (Kalleberg, 2011; Standing, 2011; Muehlebach, 2013). With the proliferation of global supply chains and the deregulation of labour markets around the world, employment relations have become increasingly flexible, impermanent, individualised and indirect. Under neo-liberal economic restructuring, workers in both the Global North and South have seen a rolling back of social protections at the same time that the bargaining power of organised labour has eroded. Although conditions of work are highly varied across industries and national contexts, a common theme is how competitiveness and profit become secured by devolving the risks of market fluctuations onto workers themselves at a time when such fluctuations are especially pronounced, accelerated and driven by forces far beyond workers' control (Barrientos, Kothari and Phillips, 2013; Breman, 2013; Eriksen, 2016).

Epidemiological and occupational health literatures show that labour precariousness creates adverse health effects. Defined as insecure, temporary or contingent work characterised by low pay and unpredictability, labour precariousness is linked to the employment of politically disempowered groups, limited worker representation in industrial relations and poor regulation of labour standards 
(Vosko, 2011; Lee and Kofman, 2012; Kalleberg and Hewison, 2013; Torres et al., 2013). These conditions can affect workplace health and safety through high employee turnover, inadequate training and weak enforcement of labour protections (Quinlan, Mayhew and Bohle, 2001; Howse, Jeebhay and Neis, 2012; Benach et al., 2014). In global supply chains, safety compliance is commonly monitored by private mechanisms that can amount to unaccountable corporate self-regulation (Walters and James, 2009; Mezzadri, 2012; De Neve and Prentice, 2017). The individualisation and privatisation of workplace bargaining relations coincides with an increasing emphasis on "behavioural" methods of occupational health and safety, whereby workers who have little control over the organisation of production are made responsible for managing risks to their safety by disciplining their own behaviour (Tombs and White, 2007; Cross, 2010; Howard, 2014).

Anthropological approaches to labour precariousness depart from epidemiological and occupational health literatures to focus on precariousness as a lived experience. Ethnographies in workplaces ranging from factories and farms to offices and nightclubs show how workers' structural vulnerabilities relate to social hierarchies and the politics of how work is organised (Molé, 2011; Funahashi, 2013; Holmes, 2013; Spyridakis, 2013). Recognising that precaritisation emerges through distinct though sometimes intersecting histories in the Global North and South, anthropological accounts point to an interrelationship between material (physical, phenomenological and economic) and social (symbolic, relational and political) dimensions of precariousness as a globally widespread but not unitary phenomenon.

This article draws together ethnographic field research from two different locations - a communitarian socialist mining cooperative in Bolivia, and a neo-liberal garment industry in Trinidad - to generate a comparative understanding of labour precariousness and its relationship to health and household reproduction. With fine-grained attention to how workers navigate everyday risks at the workplace, we theorise this relationship through the "disjunctive comparison" (Lazar, 2012) of similar phenomena in two different circumstances. Through different processes that are explained below, in both sites responsibility for health and safety has been devolved to workers themselves, who contend with these risks individually and as communities without robust support from institutions of state or civil society. Working through the two cases dialogically, we demonstrate that labour precariousness produces "precarious bodies" - working bodies that are profoundly shaped by exposure to global market forces and that must be self-managed through the daily navigation of overlapping risks. By drawing into a single frame intimate experiences of work, health and risk without losing sight of politico-economic processes at national and global scales, our approach provides some insight into the body's dialectical relationship with macroeconomic structures, and the effects of the accelerated fluctuations of global capitalism on the everyday experiences of labour and on workers' health and safety.

\section{Producing Precarious Bodies}

Workplaces, in addition to producing goods and services, always engage in the critical work of producing certain types of bodies and persons. Michel Foucault's (1979) concept of the "docile bodies" that emerged from eighteenth-century workhouses, factories and prisons provides a starting point for thinking about labouring bodies as the object of relations of power. The attributes that make a worker "desirable" are revised in different historical moments to suit changing economic configurations and 
cultural ideologies, as Emily Martin (1994) has argued in relation to post-Fordism's reliance on "flexible bodies". "Cheap labour" does not pre-exist but must be produced through the social organisation of labour markets and of production itself (Burawoy, 1979). As Melissa Wright (2006) has observed of Mexican and Chinese assembly workers, cheap labour requires, paradoxically, that bodies capable of generating enormous profit be treated as lacking value. At its extreme, cheap labour materialises as "disposable bodies" with predictable consequences for worker injury and death (Karim, 2014).

Ethnographies of labour precariousness draw attention to everyday, lived experiences of economic insecurity and their effect on the bodies and health of workers. For instance, in his 2013 ethnography of Triqui farmworkers who migrate from Oaxaca to Washington to work in the fruit harvest, Seth Holmes depicts social hierarchies of ethnicity and citizenship that structure economic opportunities and labour conditions. Arguing that illness correlates with workers' position in these hierarchies, he describes the knee pain of a migrant worker called Abelino, writing that its

social and political genesis ... could not have been clearer. His pain was caused unequivocally by the fact that he, as an undocumented Triqui man, had been excluded by both international market inequalities and local discriminatory practices from all but one narrow and particularly traumatic labour position. This occupation required him to bend over seven days a week, turning back and forth, in all kinds of weather, picking strawberries as fast as he possibly could (Holmes, 2013: 94).

Describing occupational injuries, illnesses and distress as evidence of structural violence in which bodies are sacrificed for profit, Holmes shows how racist discourses of Triqui workers' suitability for "stoop" labour normalised these conditions. Pun Ngai's (2005: 22) ethnography of electronics workers in China similarly argues that the illnesses and ailments of workers can be interpreted as moral commentary: that the "painful body" in the workplace is a "resistant body" - a body that testifies to its own exploitation.

Whereas Holmes highlights the damaging physical effects of precarious employment, Noelle Molé (2011) shows how Italy's rapid transformation into a hyper-competitive neo-liberal labour regime plays out through distinct psychological ailments among office workers. In a newly deregulated labour market, workers must surrender expectations of employment stability and state-funded social protection. As they adopt more individuated and competitive subjectivities, a form of interpersonal violence called "mobbing" has emerged, whereby employees who are perceived as weak or ineffective are bullied by co-workers and managers. The psychological treatments offered to mobbing victims medicalise labour precariousness as an individual ailment rather than a collective condition. Unlike the Triqui labourers of Holmes' account, the Italian workers experience precariousness as dispossession of the employment security and economic certainties that they had once expected. Yet in both cases, ill health and injury are theorised as the embodied effects of how production relations are organised.

Ethnographies that focus on how workers navigate the health and safety risks of their workplaces show that workers' engagement with and management of occupational health risks are inseparable from their management of other kinds of risks in their milieu. The risks associated with work are best understood as a "risk assemblage" (Root, 2008) because, as they do their jobs, workers do not separate health risks from other kinds of risk, but instead negotiate all risks informed by multiple material and social concerns (Cross, 2010; Trueba, 2014). In the flow of lived experience, workers' phenomenological engagements with their work and moment-to-moment decisions in the workplace always reflects broader considerations regarding how they and their dependents will survive. 
Through ethnographic exploration of two production systems (mining and garments) that maintain few institutional barriers to protect workers from the full thrust of market volatility, in what follows we generate a concept of "precarious bodies" to theorise the relationship between labour precariousness and health. With attention to the intimate and moment-to-moment ways in which workers navigate the occupational health risks of their work, we show how "precarious bodies" become constituted not only by their vulnerability, but also by their need to make choices in circumstances shaped by conditions far beyond their control.

\section{Settings and Methods}

This article draws together two separate studies carried out in two different employment sectors and national contexts to explore the relationship between workers' exposure to global market forces and their everyday experiences of work, health and risk. Our anthropological approach is one of “disjunctive comparison" (Lazar, 2012; Kesküla and Sanchez, 2017), in which analysis is conducted by placing "side by side" two ethnographies that were independently undertaken without comparison originally intended. This approach plumbs the context-rich and detailed findings of months of ethnographic research by selecting a single thread - in this case, workers' relationships with occupational health risks - and re-analysing fieldwork data to consider how different ethnographic evidence relates to the central theme. With rigorous contextualisation of each case, this approach allows for the development of new concepts and models without artificially flattening the distinctive particularities of separate instances.

Mei Trueba conducted research among Bolivian cooperative miners in Potosí, Bolivia (2009_ 2012), where mining is associated with high rates of occupational injuries, disease and death (Trueba, 2014). She conducted seventeen months of ethnographic research with miners, their families and the cooperative organisations in which they worked in order to understand how miners responded to occupational risks, and what factors and processes shaped their responses. Rebecca Prentice's research in Trinidad (2003-2004 and 2014) explored the devastating impact of neo-liberal restructuring on the livelihoods of local garment workers. Initial research involved fifteen months of participant observation focused on one garment factory to analyse trade liberalisation's tumultuous effects through the story of a single site (Prentice, 2015). A return fieldwork trip in 2014 explored workers' subsequent transition from factory employment to home-based outwork.

Both studies were conducted using common anthropological methods, including participant observation, writing fieldnotes and conducting interviews. Ethnographic fieldwork prioritises observation of "everyday life" within a naturalistic setting, which is paired with an exploration of individuals' own interpretations of the meanings of their actions and the actions of others. Interviews ranged from on-the-spot chats with informants to semi-structured qualitative interviews and the recording of life histories (Prentice, 2010). For both authors, the workplace was the starting point for meeting and getting to know informants; relationships were formed through extended fieldwork during which we lived in workers' neighbourhoods and endeavoured to understand their lives in situ. Ethnographic data gathered through this sustained and reflexive engagement was complemented by formal interviews with a range of relevant actors, including government officials, occupational health specialists, trade unionists, cooperative members, factory owners, and current and former garment workers or miners. In both cases ethnographic data was analysed using a combination of situational 
and narrative approaches in order to analyse micro-processes in relation to macro-structures (Clarke, 2005; Holstein and Gubrium, 2011).

We adopt the pronoun "I" to report our findings, naming in each case the relevant ethnographer. Our data emerged through long-term and empathic relationships with informants in the places where they live and work. Using the first-person singular places each of us within the research field, showing how the events that we describe occurred in specific places and times. We present stories of individuals to show how occupational risks are navigated and talked about as a routine part of everyday life; this ethnographic approach reveals workers' strategies for navigating the precarious circumstances of their livelihoods in light of their own interpretations of these circumstances.

\section{Mining in the Cerro Rico of Potosí, Bolivia (Trueba)}

The sixth-largest mineral producer in the world, Bolivia is an example of the "resource curse" thesis, or the "paradox of plenty" (Auty, 2002: 73-90). Almost half of the national territory is covered with mineral deposits, but the country is poverty-stricken. Containing perhaps the world's largest silver deposit, the Cerro Rico ("rich hill") of Potosí has been continuously mined for silver, tin and zinc since the Spanish conquest of the Andes in the early 1500s. Bolivians say with regret that enough silver has been extracted from the Cerro Rico to build a bridge from Potosí to Madrid, while enough people have died to build two bridges of bones back to Bolivia.

With a national economy based on exporting raw ores, Bolivia's socio-economic development has been subject historically to the vagaries of international mineral prices. This has resulted in cyclical episodes of privatisation and nationalisation of the mining industry following changes in national politics, with popular socialist governments rising to power following upswings in mineral prices and neo-liberal governments in periods of economic crisis. During the early 1980s, a crisis in the international tin market resulted in the bankruptcy of the state mining corporation, Corporación Minera de Bolivia (COMIBOL). Most of the state-operated mines were closed, and the remaining operations were transferred to private companies. Over 80 per cent of the mining labour force was laid off without compensation, and those workers mostly organised themselves into cooperatives to sustain their livelihoods. According to a miner named Rafael who lived through this period, in this manner miners could eke out a living by doing what they knew.

As the largest labour force in Bolivia, and with a tradition of self-advocacy and public demonstrations, miners are an important political constituency. The coalition government that came to power in 2006 led by Evo Morales' Movimiento al Socialismo (MAS) had promised to re-nationalise mining, but the risks and cost of doing so were so prohibitive that mining cooperatives were pushed instead as a compromise solution. Cooperatives now make up 96 per cent of Bolivia's mining workforce, and Potosí's cooperative miners produce 35 per cent of Bolivia's mining exports (Gandarrillas, 2013). The mine is an ethnically heterogeneous setting where city dwellers, students and

graduates work hand-in-hand with Quechuan and Aymara peasants and with the widows and children of miners who have been killed. Some 18000 male and female mineworkers between the ages of 12 and 72 worked in the Cerro Rico at the time of fieldwork.

Cooperatives rent mines of uncertain mineral content from the state in exchange for a yearly fee and a monthly percentage of the production. They are required to continuously produce ores. Cooperatives are formed by ethnically heterogeneous, self-organised work teams in which the boundaries between formal and informal employment are hard to distinguish. Cooperatives independently organise production and safety in accordance with what miners learned while working 
for COMIBOL, but with significantly lesser tools and technologies, and no government oversight. Unable to access formal loans from banks due to the uncertainty of their earnings, these miners extract minerals mostly manually and with the occasional help of drills that they borrow from unregulated mineral buyers in exchange for a cut of their earnings and the obligation to sell ores to them. Once work groups have paid a percentage of their production to the cooperative (from which the cooperative will pay the state, electric bills, etc.) and to their buyers for the borrowed tools, they divide earnings unevenly according to the productive assets each miner brought to the group.

According to Bolivian law, cooperatives must comply with labour regulations (including statutory health and safety standards), and non-compliance should result in the cessation of mining operations. But regulations are not enforced, and government presence in the mines has been reduced to the sporadic distribution of drills and air compressors, and the provision of non-compulsory health and safety training. ${ }^{1}$ For Potosí's miners, this training fails to address the persistent economic precariousness of their households and livelihoods that creates health and safety risks, injury and death in the mines. The cyclical reality of economic downturn is ever-present in miners' lives; it is heightened by the fact that the Bolivian state has traditionally responded to budget crises by cutting welfare provision and reducing enforcement of labour legislation, meaning that state assistance has always been least available when miners are most likely to need it.

Data collected during fieldwork from the local health centres and cemetery showed that over 200 miners died from work-related accidents and diseases during 2009, and almost 3000 sought primary health care after work-related injuriea. The thirty miners who died at work were all males aged 18 to 48. Since social benefits such as access to health care depend on the miners' voluntary contributions to Social Security - something many are consistently unable to afford - the actual numbers of work-related injuries and deaths can be assumed to be much higher.

\section{Trinidad's neo-liberal garment industry (Prentice)}

Trinidad's garment industry employed thousands of women in minimum-wage jobs until the early 1990s when, in the midst of a recessionary debt crisis, a structural adjustment programme backed by the International Monetary Fund (IMF) opened trade barriers to garment imports. Employment in the sector diminished by 42 per cent during the first ten years of liberalisation as local producers struggled to compete (Prentice, 2015: 9). The 2004 phase-out of the international quota system known as the Multi-Fibre Arrangement dealt another blow to local manufacturers by placing Trinidad in direct competition with producers around the world for lucrative North American and European markets.

Factory owners have attempted to increase their competitiveness by reducing costs and making their operations more responsive to a quickly changing "fast fashion" market. Large factories have shut down, replaced by a network of small, unregistered workshops that hire and fire in tune with changing retail demands. These units tend to be equipped with the second-hand equipment of the large firms. With old chairs and machines, and poor ventilation and lighting, garment workers have experienced these neo-liberal policy transformations as a decline in labour conditions, which have been accompanied by new managerial techniques that violate workers' rights to overtime payments and prenotification of overtime hours. Garment workers were widely unionised during the rapid economic

1 The extractive technology distributed by the state is not as powerful or well-maintained as that loaned by mineral buyers, so the only miners who use them are those unable to borrow equipment from elsewhere. Substandard drills and air compressors cause injuries. 
growth of Trinidad's oil boom (1971-1983). Today, with jobs in short supply, this collective voice has become muted. Garment workers perceive unions to be weak and ineffective, or primarily interested in organising more profitable sectors.

In recent years, employers have cut costs further and increased the flexibility of their operations by converting factory workers into home-based workers. Manufacturing costs are lowered by sending workers home with industrial-grade machines and a promise that they will be supplied with stitching to do for piece-rate payment. By keeping these workers in reserve, employers can periodically draw upon their labour power without having to maintain a waged workforce, nor make National Insurance contributions. Many women workers initially find this bargain attractive because it saves them the cost of commuting, and allows them to be at home for their children. Some of these home-based workers have been able to access training and microfinance through government-led schemes to convert the unemployed into "micro-entrepreneurs". Although couched in a discourse of self-responsibility and economic empowerment, for garment workers becoming a self-employed micro-entrepreneur often means engaging in the same work at home as they did in the factories, only with lower pay, fewer benefits and less visibility. Employers profit from externalising the risks of fluctuating demand from foreign and local buyers onto the workers themselves. These workers soon find themselves responsible for the costs of electricity and a secure workspace for storing the sewing machines, and also the opportunity cost of idleness when there is no work to do (Prentice, 2017).

In every type of production site, workers make their own protective equipment. In factories, workers create their own smocks, dust masks and kerchiefs out of factory scraps, and crush menthol crystals into Vaseline to apply to their nostrils to guard against dust inhalation. Workers usually know their statutory entitlements to payment on time, to overtime payments, to clean and safe conditions, and to workers' compensation in cases of injury, yet when these rights are routinely violated they have little recourse except to raise a claim in the Industrial Court. An arduous process that requires being a member in good standing of a recognised trade union, the Industrial Court is useful only in extreme cases - such as unfair dismissal - because raising a case risks being labelled as a "troublemaker" and denied future employment in the industry. Trinidadian factories that supply foreign brands must adhere to corporate codes of conduct prescribing labour conditions, but these, like national labour laws, suffer from lack of enforcement and the opacity of supply chains that now extend into informal workshops and homes.

\section{Research Findings}

\section{Bolivia: Negotiating risks and uncertainties (Trueba)}

"The problem is to take a [health] risk and the problem is as well not to take it, don't you see?" answered Don Pedro to my question about why he was going into a passage of the mine knowing that there was poisonous gas inside. He tried to reassure me by saying that he was not going in "unprotected". In addition to wearing an old COMIBOL helmet and a carbide head lamp, ${ }^{2}$ Don Pedro had asked for "permission" to work from the Pachamama: the mother earth, the Andean deity who miners believe has the power to control what happens in their lives. He had made an offering before entering the mine, with the hope that the Pachamama would reciprocate the gift by protecting his

2 If the light on a carbide lamp goes off, it can indicate the presence of carbon monoxide. 
health at work and by releasing some minerals to him.

Though his faith gave him the courage to do work that he knew might damage his health, Don Pedro did not leave his fate up to the goodwill of the Pachamama. It was May 2011. Mineral prices had been rising over a period of three months, but Don Pedro did not know whether prices would continue to rise or if they might rapidly decline. He wanted to take advantage of the high prices in order to save some money for, as he put it, periods of "thin cows" as well as to repay a debt that he had accumulated during the last drop in prices in 2007. As he said to me: "We [me, my wife and children] need to eat regardless of the prices, don't we?"

For a while Don Pedro had not been able to find good quality ores in his shaft, and his buyer was putting pressure on him to increase production - pressure that became more insistent as prices rose. The buyer had warned him that if Don Pedro was unable to produce larger quantities of goodquality ores, he would take back the drill and lend it to a more effective miner "who would make a better use of the drill". Don Pedro had been working days and nights to advance his tunnel, hoping to find another mineral vein. He was unable to afford wooden support beams, and the roof in his shaft had collapsed and filled with gas. Don Pedro knew that entering a passage that contained carbon monoxide posed a risk to his health, but he assessed this health risk together with all the other risks and uncertainties that affected him, and with the small degree of power he had to manage them. For cooperative miners working in Potosís Cerro Rico, accepting health risks is a risk management strategy. This is illustrated in the words of a 43-year-old cooperative miner called Gumersindo:

We [cooperative miners] face many risks ... not only at work but also at home.... And we also worry about the dangers that affect our children, wives, friends and families. We are here [the Cerro Rico] and do what we do because we are responsible for our families ... but we cannot prevent them all [the risks] ... only very few [risks] we can try to avoid. I, for instance ... I do this by taking other risks, usually to my own health.... I am not the only one! I have seen many others do the same here.... We all do it; we live and die for the mine, don't you see? This is the hold life has ... at least for us! At least for me.... Someone very smart and very malicious positioned us here and left us to yield our own luck ... and this is how we do it: by taking some risks to prevent some other risks so that our children won't have to.

While the health-risk defiance characteristic of Potosís cooperative miners is essential for the entire family to get by, it can worsen the precariousness of their households. Injury and death due to dynamite explosions, collapsing shafts and gas poisoning are frequent. Given the prevalence and extremity of these hazards, miners bitterly say that developing a lung disease from dust inhalation indicates that one has been "lucky" enough to survive many years working in the mine. Miners worry most about an injury that will incapacitate them. In such cases, a miner's wife may find herself with children to feed single-handedly and a disabled husband to care for while being unable to access state benefits due to her husband's scarce contributions to Social Security. Many cooperatives offer the widow or eldest son the opportunity to become a miner, as informal compensation for a husband's accident.

This was the case of Doña María, a 35-year-old woman who moved with her family from the countryside to Potosí in search of a better livelihood and quality of life. After the death of her husband, Doña María did not want her eldest son (who was still school age) to work in the mine. She accepted the cooperative's offer of employment for herself. However, fearing what might happen to her children if she were injured or killed, she worked as a scavenger collecting the ores lying around the cooperative 
mine's entrance. As a scavenger Doña María would be safer but only have access to low-quality ores. I met with her again a few months after the death of her husband, during which time she had left the room they had rented in town and moved with her children to live in the Cerro Rico. They lived, with neither water nor electricity, in a small hut previously used by the cooperative to store drills. "Living here, I can work all day while taking care of my children", she said proudly.

Often a young widow will marry another miner, which can result in the new husband rejecting her children or sending them to work in the mine. Doña María was pleased that she had not needed to remarry. However, she had visibly aged and lost weight since I had last seen her; she had bruises and scars on her legs and arms, and her face showed the signs of sunburn and fatigue. "It's nothing", she said; "the real dangers are inside [the mine]". She added, "Besides, I am used to it now; I no longer feel the pains in my body".

Just by the entrance of the hut there were three piles of mineralised rocks. Doña María explained that she was waiting for the buyer to come and collect them with the truck. "As soon as he pays me I will go to town to buy water and food for the week", she told me. "Living here I do not pay rent, so I can manage." It had taken her two weeks to gather the three piles of mineralised rocks, and she seemed happy that due to the high mineral prices this would allow her to buy water and food for her and her children for the entire week. ${ }^{3}$ She had also struck an agreement with a cooperative miner for her to remove non-mineralised rocks from his deposit in order to increase its quality before being sold. This required her to jump on top of the pile of rocks every time the miner emptied his wagons. Doña María and her little helpers - as she called her children - were paid US\$1.50 per day to do this job, money that she used to purchase school goods. "You see?" she said. "We are managing without risking our lives in the mine or marrying someone else!"

\section{Trinidad: Embodying market fluctuations (Prentice)}

When Rhonda arrived at work each morning, she never knew what she would be required to do that day. The small factory that employed her manufactured clothing for a chain of brand-name stores, and it specialised in producing changing fashions under tight deadlines. The factory sought to be nimble and market-responsive by using a "hyper-Taylorist" production regime (Collins, 2001), in which a highly skilled worker like Rhonda would have little decision-making power over the pace, type or sequence of her work. One moment she might be required to operate a cutting machine, then without warning be told to stop cutting and start stitching buttonholes. Line managers shouted at workers to increase their speed when production demands were high. Workers described this work environment as punitive and belittling, making them feel, as many told me, "like a little girl at school", or worse, as subject to "a slave driver situation".

Like many of the Trinidadian garment factories still in operation, Rhonda's employer capitalised upon the closure of large firms by buying up their second-hand machines at low prices. Workers used their own bodies to make up the deficiencies of this worn-out equipment. One afternoon I watched Rhonda complain to her supervisor that the button-tacking machine was injuring her arm. The machine was old and frequently broke needles, so the line manager instructed Rhonda to wrap her arms around the machine's base to cushion its vibrations and prevent the needle from snapping off. When Rhonda complained that the machine hurt her arm when cradled in this way, her employer told

${ }^{3}$ As mineral prices increase, so do local food prices in Potosí. 
her that if she didn't want to work on the machine she could quit. Faced with the threat of unemployment, Rhonda continued to work on the broken machine despite the pain it caused her.

Workers put their own bodies into the breach of broken machines to make them work. Rhonda's capitulation to the threat of dismissal confirmed her sense of powerlessness and an awareness that she was expected to manage workplace health risks herself. Without external actors - trade unions or state agencies - to whom she could appeal for assistance, grievances played out through dyadic relationships between employers and workers. Hers was considered a "good" employer, providing minimum wage employment in an air-conditioned factory. Even if she managed to raise a successful claim of unfair dismissal in the Industrial Court, Rhonda would still be out of the best job she could hope to get. The demands of cheap, "flexible" production to keep pace with global competition risk damaging workers' bodies; the fear of losing their jobs drives workers to accept such risks. In periods when production demands are high, garment workers experience musculoskeletal pain and fatigue; "headache tablets" (paracetamol) help them cope. One seamstress who had quit working in a factory told me that she decided to leave the high-pressure job “when I couldn't afford the medicine no more”.

In fact, workers evaluate risks relationally, with bodily risks gauged in respect to other hazards. This is illustrated with Rhonda's case, and also with workers' sense of safety inside the workplace. At one small workshop housed above a fabric store, where I conducted participant observation in 2004 and returned in 2014 to find the worksite little changed, the only entrance was a gated door at the top of an external staircase. Like many buildings in Trinidad, the windows were barred with "burglarproofing" and the doorway was secured with a locked gate during work hours. Bolts of dusty fabric piled in the corner, hundreds of paper patterns hung from ceiling racks, and the wooden interior of the workshop made the site susceptible to fire. But without any local factory fires within memory, and with no visits from safety inspectors in years, it should not be surprising that workers felt more secure being locked into the factories in these conditions because the threat of robbery was far more present in their everyday lives (Prentice, 2015: 173-93).

Most Trinidadian women who work in garment production describe a "regular" job - permanent employment in a well-maintained factory with stable hours and pay - as their preference. With the intensification and casualisation of labour that has accompanied the rise of flexible production and "fast fashion", workers can be nostalgic for the less erratic pace of work in the large, Fordist firms of the 1980s and 1990s, where piece-rate payment put them in control of their earnings, and strong unions meant higher wages and better labour standards. The loss of such jobs has been experienced in embodied ways, from the pain of injury from working on an old sewing machine in a small workshop, to the homeworker's "stress" of periods without any income when there is no work available, interspersed with the manic pace of having too much stitching to complete.

When factories began outsourcing to homeworkers, workers embraced the change because they thought they would be able to earn the same money without the time and expense of travelling to a factory, and be present for children at home. But the demands of their employers have fluctuated wildly, based not only on seasonal clothing demands but also on hard-to-predict cycles of fashion for foreign buyers. Homeworkers call this uneven production pace "a hustle", requiring unstinting effort when orders are issued, followed by agonising and anxiety-inducing periods of idleness when there is no work to do. A worker named Monica explained this stress as just as detrimental to quality of life as the stress of rising food and housing costs: "You see prices going up all the time. That's a stress. When there is work, that's a stress. And [when you are waiting wondering] where is the work? That's a stress." Homeworkers were more available to the ongoing needs of children and a household; a greater 
proportion of their time became engaged in the kinds of reproductive labour that is unrecognised and uncompensated. This is an additional burden that they did not have to shoulder when they were factory workers forced to leave their children with grandparents or pay for childcare.

\section{Fluctuating Markets, Intensifying Risks}

When Don Pedro enters a mineshaft that he knows may expose him to poisonous gas, his assessment of this health risk is profoundly shaped by, and inseparable from, the assemblage of many other risks and uncertainties he faces every day. As a cooperative miner, his livelihood is tied not only to the amount of ore the mountain releases to him, but also to the price it will fetch on the international market. Don Pedro's work and the risks he takes, then, are highly tuned to market fluctuations: when prices are high, he works hard to earn enough to buffer against the inevitable economic downturn; at the same time, though, when prices are low he must exert extra effort to make a living. These risks manifest as health risks to his body: pressing deeper into the mine raises the risk of carbon monoxide poisoning or the mine's collapse, but these risks are weighed against the ongoing need to earn enough to survive into the future. For miners on the Cerro Rico, the relationship between health risks and labour precariousness is centrally about market fluctuations in the price of ore, and how these fluctuations define the workers' lives and livelihoods. Precarious bodies therefore bear the imprint of global market forces - in assaults to their bodily well-being and health, in workplace injuries and in workplace deaths.

The livelihoods of garment workers in Trinidad are shaped by market flux in different ways. Stable factory jobs in the 1970s and early 1980s served a protected domestic market during a period of economic growth fuelled by the country's oil boom. The recession and structural adjustment that followed "opened" Trinidad's garment sector to global competition at precisely the moment when neo-liberal restructuring placed garment-producing countries in direct and ruthless competition with each other, particularly over contracts to produce quickly changing "fast fashion". Less likely to be securely employed with a guaranteed wage, Trinidadian women working in the industry have seen their jobs converted into temporary, provisional and precarious arrangements. Working with old equipment in deteriorating conditions, garment workers are expected to manage the risks to their health and safety in a situation of unequal power. In small workshops where they may be hired and fired in tune with fluctuating demand, workers have not been able to sustain the collective labour voice established by workers in large-scale factories a generation ago. Homeworking is an extreme example of these individuating trends, as the risks of market competition are externalised onto workers who wait for stitching to become available and then work with "hustle" and "stress" when it is.

Mining and garment production are two industries profoundly shaped by market fluctuations: mining because of rising and falling prices, and garments because of the oscillating labour demands dictated by quickly changing fashion trends. Workers' direct experience of market volatility is made more pronounced by the structure of global trade and the failure of national and local worker protections. In Trinidad, garment workers have seen their jobs devolve from formal factory settings where work is regular and predictable to informal workshops and homes where workers take on many of the business costs of market uncertainty formerly absorbed by their employers. In the small number of factories still in operation, garment workers' labour rights are routinely violated without penalty, given the state's neglect of workers' welfare within such a small and shrinking sector, and the weakness 
of trade unions nationally.

In Bolivia, since the bankruptcy of the national mining industry in the 1980s following the collapse of international tin prices, the state has promoted mining cooperatives because they help insulate the national economy against price shocks. Cooperatives generate export earnings regardless of how low prices are, because cooperative miners will always work. The state's reliance on miners to cushion the country against price fluctuations leaves miners in a vulnerable position. In periods of economic downturn, the Morales government asks them to increase production to meet the fall (La Razón, 2011). Although this government has so far maintained welfare provisions regardless of prices, the state has traditionally saved costs by cutting social entitlements and welfare provision during downturns, and so miners no longer trust the state to provide for them. Cooperative miners' current vulnerability to market volatility is therefore heightened by the previous governments' selective cuts to social welfare.

As a global phenomenon, labour precariousness is connected to a crisis of social reproduction under neo-liberal reforms (Lee and Kofman, 2012). Where the cost of living exceeds the amount that workers are paid - and where state welfare does not make up the shortfall - families cannot sustain a nutritious diet, and workers will be unable to improve the living conditions and educational opportunities of dependents (Attanapola, 2005; Van Hoecke, 2008). Miners in the Cerro Rico understand their responsibility to self-manage their own safety at work; they fear that if they become injured or killed their dependents will suffer. Although cooperatives are legally obligated to pay compensation, many are too poor to do so, and cooperatives that can afford to pay are not compelled to by the state. In Bolivia and Trinidad, the hardships and uncertainties associated with these industries mean that, regardless of parents' efforts at generating sufficient income to meet household needs, children can become slowly introduced to mining and garment work as informal, and unpaid, "little helpers".

These two case studies confirm Robin Root's (2008) finding that that workers will negotiate health and safety risks as a "risk assemblage" because they do not separate immediate workplace risks from the need for a livelihood in order to survive. Bolivian cooperative miners evaluate occupational health risks together with all other risks and uncertainties that affect them and their dependents, such as mineral prices, access to extractive tools and household income needs. Their responses to the health risks they face at work are shaped by their ability to manage all the risks and uncertainties that simultaneously affect them. For instance, unable to access widowhood benefits and receiving no compensation for their husbands' work-related deaths, miners' widows often choose to become miners themselves. To avoid the necessity of marrying someone who might send their children to work in the mines, widows will take the health risks of mining upon themselves. For Trinidadian women made to operate broken sewing machines, they evaluate physical harm in relation to their livelihood options; a garment factory job may be valuable enough to accept working with physical pain. Garment workers who have experienced the ever-present threat of robbery and violence in their communities would choose to be locked "safely" inside a workshop despite the risk of fire.

Although experiences vary across industries and national contexts, comparing findings from these two field sites reveals four uniting themes that can be taken into a single analytic frame. First, political economy and global market forces manifest in the day-to-day, intimate practices of work - in production demands, in workplace tempos, in the pain of injury, and in the calculated decisions to risk safety in order to make a living in a context of economic uncertainty. Second, the experience of these market forces becomes more pronounced with the failure of the state to create sustainable protections 
for workers against the volatility of the market. Despite occupational health and safety legislation in Bolivia and Trinidad that mandates safe workplaces, workers' compensation for occupational injury or death, and informing employees of their rights, these regulations are only patchily enforced. Third, at the level of lived experience, "occupational health and safety" risks are indivisible from other kinds of risks - to income, to livelihoods and to a family's survival - which precarious workers navigate as an occupational risk assemblage. Finally, "precarious bodies" are a site of risk management, with workers making calculated and deliberate decisions about risks of many kinds. Forced to choose in many instances not between what is "safe" or "unsafe" but instead negotiating gradations of safety set against risks to income and to the household, workers make choices that they know will likely harm their health in either the short- or long-term. More broadly, these bodies are made to serve as a risk management tool for businesses, for national governments and for capital because they are used to absorb and thereby contain the volatility of the market.

\section{Conclusion}

Potosí's cooperative miners and Trinidadian garment workers face different work contexts, risks, and political and social environments. Both groups of workers, in their different ways, are subject to labour precariousness: unpredictable and insecure livelihoods that are tightly tied to international market fluctuations. Bodily labour is necessary to produce ore and garments, and yet the industries' reliance on these bodies does not translate into high value or regard for them. On the contrary, the miners who compete for access to minerals and the garment workers attempting to piece together livelihoods describe their occupations as consuming their bodies. "Disjunctive comparison" (Lazar, 2012) places these phenomena side by side to reveal how in both Bolivia and Trinidad international market fluctuations affect intimate experiences of work and the strategies that workers adopt to navigate workplace risks.

Drawing together evidence from two diverse sites has helped us theorise the relationship between labour precariousness and health. Labour precariousness produces precarious bodies. Precarious bodies are strategic, choosing bodies, but positioned in situations of exploitation and risk. The choices workers can make to protect their livelihoods are so restrictive that they often harm their health and reproduce rather than disrupt their sense of precariousness. Workers also use their bodies to manage economic risks. Labour precariousness imperils workers' health, because workers are made to choose - knowingly - from among options that reflect their own vulnerability and disempowerment. When workers take occupational risks that adversely affect their health in the short- or long-term, they are made complicit in the reproduction of their own precariousness.

In line with the dominant approach to occupational health and safety, health and safety specialists in Bolivia and Trinidad emphasise the importance of individual workers' "knowledge" of risks to shape "desirable" responses of risk management (see for instance Alli, 2008; ILO, 2011; Howard, 2014). But placing "precarious bodies" at the centre of our analysis suggests the limitations of this behaviouralist approach by emphasising not only that workers understand health and safety risks, but also that they choose from among them in light of other risks. We therefore call for a stronger role of ethnography not only in the analysis of labour precariousness, but also in the field of occupational health and safety to explain how moment-to-moment health and safety decisions are 
profoundly structured by macroeconomic forces operating far beyond workers' direct field of experience, affecting workers' labour in immediate and intimate ways.

\section{REFERENCES}

Alli, B. (2008) Fundamental Principles of Occupational Health and Safety. Geneva: ILO.

Attanapola, C.T. (2005) Experiences of Globalization and Health in the Narratives of Women Industrial Workers in Sri Lanka. Gender, Technology and Development, 9(1): 81-102.

Auty, R. (2002) Sustaining Development in Mineral Economies: The Resource Curse Thesis. New York: Routledge.

Barrientos, S., U. Kothari and N. Phillips (2013) Dynamics of Unfree Labour in the Contemporary Global Economy. The Journal of Development Studies, 49(8): 1037-1041.

Benach, J., A. Vives, M. Amable, C. Vanroelen, G. Tarafa and C. Muntaner (2014) Precarious Employment: Understanding an Emerging Social Determinant of Health. Annual Review of Public Health, 35: 229-253.

Breman, J. (2013) A Bogus Concept? New Left Review, 84: 130-138.

Burawoy, M. (1979) Manufacturing Consent: Changes in the Labour Process under Monopoly Capitalism. Chicago: University of Chicago Press.

Clarke, A. (2005) Situational Analysis: Grounded Theory after the Postmodern Turn. London: Sage.

Collins, J.L. (2001) Flexible Specialization and the Garment Industry. Competition \& Change, 5(2): 165-200.

Cross, J. (2010) Occupational Health, Risk, and Science in India's Global Factories. South Asian History and Culture, 1(2): 224-238.

De Neve, G. and R. Prentice (2017) Introduction: Rethinking Garment Workers' Health and Safety. In Unmaking the Global Sweatshop: Health and Safety of the World's Garment Workers, edited by R. Prentice and G. De Neve. Philadelphia, PA: University of Pennsylvania Press.

Eriksen, T.H. (2016) Overheating: An Anthropology of Accelerated Change. London: Pluto.

Foucault, M. (1979) Discipline and Punish: The Birth of the Prison, trans. by Alan Sheridan. New York: Vintage Books.

Funahashi, D.A. (2013) Wrapped in Plastic: Transformation and Alienation in the New Finnish Economy. Cultural Anthropology, 28(1): 1-21.

Gandarrillas, M. (2013) Extractivismo y Derechos Laborales: Dilema del caso Boliviano. In Empresas Transnacionales en América Latina. Análisis y Propuestas del Movimiento Social y Sindical, edited by Juan Hernández Zubizarreta, Mikel de la Fuente Lavín, Andrea De Vicente Arias and Koldo Irurzun Ugalde. Cochabamba: CEDIB.

Holmes, S.M. (2013) Fresh Fruit, Broken Bodies: Migrant Farmworkers in the United States. Berkeley: University of California Press.

Holstein, J.A. and J.F. Gubrium (eds.) (2011) Varieties of Narrative Analysis. London: Sage.

Howard, P. (2014) Occupational Health and Safety. In The Wiley Blackwell Encyclopedia of Health, Illness, Behaviour, and Society, edited by W. Cockerham, R. Dingwall and S.R. Quah. Oxford, UK: Wiley Blackwell.

Howse, D., M.F. Jeebhay and B. Neis (2012) The Changing Political Economy of Occupational Health and Safety in Fisheries: Lessons from Eastern Canada and South Africa. Journal of Agrarian Change, 12(2-3): 344 363. 
International Labour Organization (ILO) (2011) Encyclopaedia of Occupational Health and Safety. Geneva: ILO.

Kalleberg, A.L. (2011) Good Jobs, Bad Jobs: The Rise of Polarized and Precarious Employment Systems in the United States, 1970s to 2000s. New York: Russell Sage.

Kalleberg, A.L. and K. Hewison (2013) Precarious Work and the Challenge for Asia. American Bebavioural Scientist, 57(3): 271-288.

Karim, L. (2014) Disposable Bodies: Garment Factory Catastrophe and Feminist Practices in Bangladesh. Anthropology Now, 6(1): 52-63.

Kesküla, E. and A. Sanchez (2017) Everyday Barricades: Banality and the Paradox of Struggle in Global Trade Unions. Paper presented at "Labour Politics in an Age of Precarity", University of Cambridge, April 21.

La Razón (2011) Caen Precios de Minerales: COMIBOL Dice Que es Fugaz. La Razoón, June 15. Available at http:// www.la-razon.com/index.php? url=/economia/Caen-precios-minerales-Comibolfugaz_0 1413458677.html [accessed 20 May 2016].

Lazar, S. (2012) Disjunctive Comparison: Citizenship and Trade Unionism in Bolivia and Argentina. Journal of the Royal Anthropological Institute, 18(2): 349-368.

Lee, C.K. and Y. Kofman (2012) The Politics of Precarity: Views Beyond the United States. Work and Occupations, 39(4): 388-408.

Martin, E. (1994) Flexible Bodies: The Role of Immunity in American Culture from the Days of Polio to the Age of AIDS. Boston: Beacon Press.

Mezzadri, A. (2012) Reflections on Globalisation and Labour Standards in the Indian Garment Industry: Codes of Conduct Versus "Codes of Practice" Imposed by the Firm. Global Labour Journal, 3(1): 40-62.

Molé, N.J. (2011) Labor Disorders in Neoliberal Italy: Mobbing, Well-being and the Workplace. Bloomington, IN: Indiana University Press.

Muehlebach, A. (2013) On Precariousness and the Ethical Imagination: The Year 2012 in Sociocultural Anthropology. American Anthropologist, 115(2): 297-311.

Prentice, R. (2010) Ethnographic Approaches to Health and Development Research: The Contributions of Anthropology. In The SAGE Handbook of Qualitative Methods in Health Research, edited by I. Bourgeault, R. Dingwall and R. de Vries. London: Sage.

Prentice, R. (2015) Thiefing a Chance: Factory Work, Illicit Labor, and Neoliberal Subjectivities in Trinidad. Boulder, CO: University of Colorado Press.

Prentice, R. (2017) Microenterprise Development, Industrial Labour, and the Seductions of Precarity. Critique of Anthropology, 37(2): 201-222.

Pun, N. (2005) Made in China: Women Factory Workers in a Global Workplace. Durham, NC: Duke University Press.

Quinlan, M., C. Mayhew and P. Bohle (2001) The Global Expansion of Precarious Employment, Work Disorganization, and Consequences for Occupational Health: A Review of Recent Research. International Journal of Health Services, 31(2): 335-414.

Root, R. (2008) “Controlling Ourselves, By Ourselves”: Risk Assemblages on Malaysia’s Assembly Lines. Medical Anthropology, 27(4): 405-434.

Spyridakis, M. (2013) The Liminal Worker: An Ethnography of Work, Unemployment and Precariousness in Contemporary Greece. London: Routledge.

Standing, G. (2011) The Precariat: The Dangerous New Class. New York: Bloomsbury Academic.

Tombs, S. and D. White (2007) Safety Crimes. Cullompton, UK: Willan.

Torres, R., R. Heyman, S. Munoz, L. Apgar, E. Timm, C. Tzintzun, C.R. Hale, J. Mckiernan-Gonzalez, S. Speed 
and E. Tang (2013) Building Austin, Building Justice: Immigrant Construction Workers, Precarious Labour Regimes and Social Citizenship. Geoforum, 45: 145-155.

Trueba, M.L. (2014) "Looking at Risk with Both Eyes": Health and Safety in the Cerro Rico of Potosí (Bolivia). Doctoral thesis, Institute of Development Studies, University of Sussex.

Van Hoecke, E. (2008) Estudio Canasta Familiar; Atocha, Telamayu, Animas, Huanuni, Machacamarca, Oruro, Potosí, El Alto. La Paz: Red Nacional de Mujeres y Minería.

Vosko, L.F. (2011) Managing the Margins: Gender, Citizenship, and the International Regulation of Precarious Employment. New York: Oxford University Press.

Walters, D. and P. James (2009) Understanding the Role of Supply Chains in Influencing Health and Safety at Work. Wigston, Leicester: IOSH.

Wright, M. (2006) Disposable Women and Other Myths of Global Capitalism. New York: Routledge.

\section{ACKNOWLEDGEMENTS}

Research in Bolivia and Trinidad was funded by the ICO Foundation, the Spanish Agency for International Cooperation and Development (AECID), the Wenner-Gren Foundation and the University of Sussex. This work has benefited enormously from the feedback of audiences at the University of Kent and the University of Sussex; we thank Andrew Sanchez, Dinah Rajak and Catherine Dolan for inviting us to present our work.

\section{BIOGRAPHICAL NOTES}

ReBeCCA PRENTICE is senior lecturer in Anthropology at the University of Sussex. She is co-editor, with Geert De Neve, of Unmaking the Global Sweatshop: Health and Safety of the World's Garment Workers (University of Pennsylvania Press, 2017). In 2015 she was awarded the Society for the Anthropology of Work Book Prize for Thiefing a Chance: Factory Work, Illicit Labor and Neoliberal Subjectivities in Trinidad (University Press of Colorado, 2015). [Email: r.j.prentice@sussex.ac.uk]

MeI L. TRuebA is lecturer in Global Health at the Brighton and Sussex Medical School. Her research is predominantly concerned with workers' well-being and the politics of occupational health and safety at individual, organisational, national and global levels. [Email: M.Trueba@bsms.ac.uk] 